\title{
ORIGINALS
}

\section{Calcium Induced Glucagon Release in Monolayer Culture of the Endocrine Pancreas. Studies with Ionophore A23187}

\author{
C. B. Wollheim, B. Blondel, A. E. Renold and G. W. G. Sharp \\ Institut de Biochimie Clinique and Institut d'Histologie et d'Embryologie, Université de Genève, Genève, Switzerland
}

Summary. The possible role of $\mathrm{Ca}^{2+}$ in glucagon release has been investigated by the use of ionophore A23187. This ionophore permits $\mathrm{Ca}^{2+}$ entry down a suitable concentration gradient by complexing and releasing $\mathrm{Ca}^{2+}$, thereby acting as a carrier in plasma membranes. Cultured cells obtained by enzymatic digestion of pancreases from newborn rats were studied on the third day of culture. As expected the effects of the ionophore were dependent upon the presence of $\mathrm{Ca}^{2+}$ in the medium. However, either stimulation or inhibition of glucagon release resulted when different concentrations of ionophore and $\mathrm{Ca}^{2+}$ were used. With $1.0 \mathrm{mM} \mathrm{Ca}^{2+}$ in the medium, glucagon release was stimulated in the presence of 0.01 and $0.1 \mu \mathrm{g} / \mathrm{ml}$ ionophore, but inhibited in the presence of 3.0 and $10.0 \mu \mathrm{g} / \mathrm{ml}$. With $0.1 \mu \mathrm{g} / \mathrm{ml}$ ionophore, glucagon release was stimulated by 0.3 and $1.0 \mathrm{mM} \mathrm{Ca}^{2+}$ but not by $2.5 \mathrm{mM} \mathrm{Ca}^{2+}$. With $10 \mu \mathrm{g} / \mathrm{ml}$ ionophore glucagon release was stimulated by $0.03,0.1$ and $0.3 \mathrm{mM} \mathrm{Ca}^{2+}$, whereas at $1.0 \mathrm{mM}$, glucagon release was depressed. These findings suggest that by increasing $\mathrm{Ca}^{2+}$, glucagon is released from the A-cells, whereas too large an increase in $\mathrm{Ca}^{2+}$ is inhibitory. The effect to stimulate release was not completely specific for $\mathrm{Ca}^{2+}$ in that while the ionophore did not stimulate release in the presence of either $\mathrm{Mg}^{2+}$ or $\mathrm{Sr}^{2+}$ in the absence of $\mathrm{Ca}^{2+}$, it did stimulate release when $\mathrm{Ba}^{2+}$ was tested. Furthermore $\mathrm{Ba}^{2+}$ at $0.3 \mathrm{mM}$ was stimulatory even in the absence of ionophore. Glucagon release in the absence of ionophore was also enhanced by addition of $30 \mathrm{mM} \mathrm{Ca}{ }^{2+}$ or by omission of $\mathrm{Ca}^{2+}$ from the medium. It is concluded that $\mathrm{Ca}^{2+}$, which plays an essential role in the stimulus-secretion coupling in several different cell types, may be involved in the stimulation of glucagon release from the A-cells of the pancreas.
Key words: Glucagon release, monolayer culture, ionophore A23187, calcium, endocrine pancreas.

Calcium plays an essential role in the secretion of hormones from endocrine glands and in the control of numerous biological mechanisms. Studies on the effects of $\mathrm{Ca}^{2+}$ have been facilitated recently by the use of divalent cation ionophores, such as A23187, a carboxylic acid antibiotic [1] with the ability to transport divalent cations across biological membranes [2-5]. By the use of this agent and a favourable concentration gradient for $\mathrm{Ca}^{2+}$ across cell membranes it is possible to introduce $\mathrm{Ca}^{2+}$ into the cell interior in a concentration dependent manner. Thus the ionophore has been used to study the effects of $\mathrm{Ca}^{2+}$ on a variety of functions, including histamine release from mast cells [6-7], fluid secretion from fly salivary gland [8], $\mathrm{K}^{+}$release from the parotid gland [9], amylase secretion from the exocrine pancreas $[10,11]$, dopamine release from synaptosomes [12], ATP release from platelets [13], vasopressin release from neurohypophysis [14], and hormone release from islets of Langerhans [15-18]. In all these studies it was shown that physiological secretion processes could be stimulated by increasing the amount of cell $\mathrm{Ca}^{2+}$ in the absence of other known physiological stimulators for these responses. In the case of insulin release, $\mathrm{Ca}^{2+}$ entry facilitated by the ionophore A23187 was shown to stimulate and sustain insulin release [15]. The release occurred at non-stimulatory glucose concentrations and was dependent upon the $\mathrm{Ca}^{2+}$ concentration available for entry. 
Thus investigations using the ionophore were performed to study the role of $\mathrm{Ca}^{2+}$ in the glucagon release system. As in our previous study with the ionophore [15] the monolayer culture of newborn rat pancreas, which provides near maximal exposure of cell surfaces and responds in a physiologic manner to modulators of glucagon release [19], was used as the test preparation.

\section{Material and Methods}

The culture procedure for endocrine pancreas has been described previously $[19,20]$. In brief (for one culture preparation) $100-120$ pancreases from 1-3 day old Wistar rats were excised using sterile technique. The pooled pancreases were cut into pieces 1-2 $\mathrm{mm}$ in diameter. After one washing in calcium and magnesium-free phosphate buffered saline (PBS) the pieces of pancreas were submitted to approximately ten consecutive treatments with a mixture of trypsin and collagenase in calcium and magnesium-free PBS, containing $2.8 \mathrm{mM}$ glucose at $37^{\circ} \mathrm{C}$. The $3-4$ initial supernatants were discarded. The subsequent supernatants containing isolated cells were kept and diluted with cold $\left(+4^{\circ} \mathrm{C}\right)$ culture medium 199 containing $10 \%$ calf-serum, $14 \mathrm{mM}$ sodium bicarbonate, 16.7 $\mathrm{mM}$ glucose and Na-penicillin $\mathrm{G} 400 \mathrm{U} / \mathrm{ml}$. The pooled supernatants were centrifuged at $150 \times \mathrm{G}$ and the packed cells resuspended in medium 199. The final suspension was diluted to contain about 500000 cells $/ \mathrm{ml}$ and plated in plastic Petri dishes. By this procedure 40-50 culture dishes were obtained. The cells were cultured at $37^{\circ} \mathrm{C}$ in the culture medium 199 in an incubator with automatic $\mathrm{pH}$ regulation. About $14 \mathrm{~h}$ after plating, at a time when a major portion of fibroblastoid cells, but only a minor portion of the epithelioid cells, had attached to the bottom of the culture dishes, the supernatants were decanted into new Petri dishes and the residual dishes discarded. As reported previously $[19,20]$ this decantation yielded cultures which were rich in epithelioid cells. 44 hours after plating, when the epithelioid cells had attached to the bottom of the dish and rearranged in clusters of varying size, the cells were washed and fresh culture medium containing $5.6 \mathrm{mM}$ glucose was added. On the third day of culture the cells were studied under conditions of short incubation in Krebs-Ringer bicarbonate buffer (KRB). By this time amylase activity could no longer be detected in the culture medium and exocrine cells were devoid of zymogen granules when examined by electron microscopy [21].

The KRB buffer contained $0.5 \%$ dialyzed bovine serum albumin, 250 Kallikrein inhibitory units $/ \mathrm{ml}$
Trasylol and $2.8 \mathrm{mM}$ glucose. The ionic composition of the standard KRB-buffer was the following: $\mathrm{Na}^{+}$ $142.9 \mathrm{mM}, \mathrm{K}^{+} 5.8 \mathrm{mM}, \mathrm{Ca}^{2+} 2.5 \mathrm{mM}, \mathrm{Mg}^{2+} 1.2 \mathrm{mM}$, $\mathrm{Cl}-128.4 \mathrm{mM}, \mathrm{SO}_{4}{ }^{2-} 1.2 \mathrm{mM}, \mathrm{H}_{2} \mathrm{PO}_{4}{ }^{-1} 1.2 \mathrm{mM}$ and $\mathrm{HCO}_{3}{ }^{-} 24.4 \mathrm{mM}$. Calcium depleted media were obtained by omission of $\mathrm{CaCl}_{2}$ from the standard buffer. To the calcium depleted buffer varying concentrations of $\mathrm{CaCl}_{2}, \mathrm{MgSO}_{4}, \mathrm{SrCl}_{2}$ or $\mathrm{BaCl}_{2}$ were added where appropriate. A23187 was dissolved in dimethyl sulfoxide before addition to the test media; dimethyl sulfoxide at a final concentration of $0.33 \%$ had no effect alone, but was added to control media in all cases where the ionophore was being tested. In the experiments in which $\mathrm{Ca}^{2+}$ concentrations up to 30 $\mathrm{mM}$ were used, the phosphate concentration was reduced to $0.1 \mathrm{mM}$ to avoid precipitation of calcium phosphate.

Incubations were carried out over $30 \mathrm{~min}$ or $1 \mathrm{~h}$ at $37^{\circ} \mathrm{C}$ and $\mathrm{pH}$ was maintained at $7.40 \pm 0.05$. Samples taken at the end of the incubation were centrifuged 15 $\mathrm{min}$ at $3500 \mathrm{xG}$, decanted and then frozen and stored at $-20^{\circ} \mathrm{C}$ until assay. Immunoreactive glucagon (IRG) was measured by radioimmunoassay using rabbit anti-porcine glucagon serum, and pork glucagon as standard. Antibody-bound hormone was separated from free hormone using dextran-coated charcoal as described by Unger et al. [22]. At the doses used, the ionophore did not interfere with the assay. Glucagon content of the cultured cells was determined after incubation by washing the cells twice with PBS, then extracting with $0.15 \mathrm{~N} \mathrm{HCl}$ in $75 \%$ ethanol and assaying after dilution.

Results are expressed as means \pm SEM. Petri dishes were paired before the experiments into test and control dishes. Statistical analysis was by the paired Student's t-test.

The chemicals employed and their sources were as follows: trypsin (Difco Laboratories, Detroit, Mich.), collagenase (Worthington Biochemical Corp., Freehold, N. J.), medium 199 (Grand Island Biological Co., Grand Island, N. Y.), sodium-penicillin G (Chas. Pfizer and Co., Inc., New York, N. Y.), Petri dishes (Falcon Plastics, Oxnard, Calif.), bovine serum albumin (Behringwerke A.G., Marburg, FRG), Trasylol (kindly provided by Dr. H. Ruff, Bayer Pharma A. G., Zurich, Switzerland), A23187 (kindly provided by Dr. O. Behrens, Eli Lilly, Indianapolis, Ind.), dimethyl sulfoxide (Merck A. G., Darmstadt, FRG), glucagon antiserum $30 \mathrm{~K}$ (generously provided by $\mathrm{Dr}$. R. H. Unger, University of Texas, Southwestern Medical School, Dallas, Texas. Glucagon was a gift from Dr. L. Heding, Novo Research Institute, Copenhagen, Denmark. 


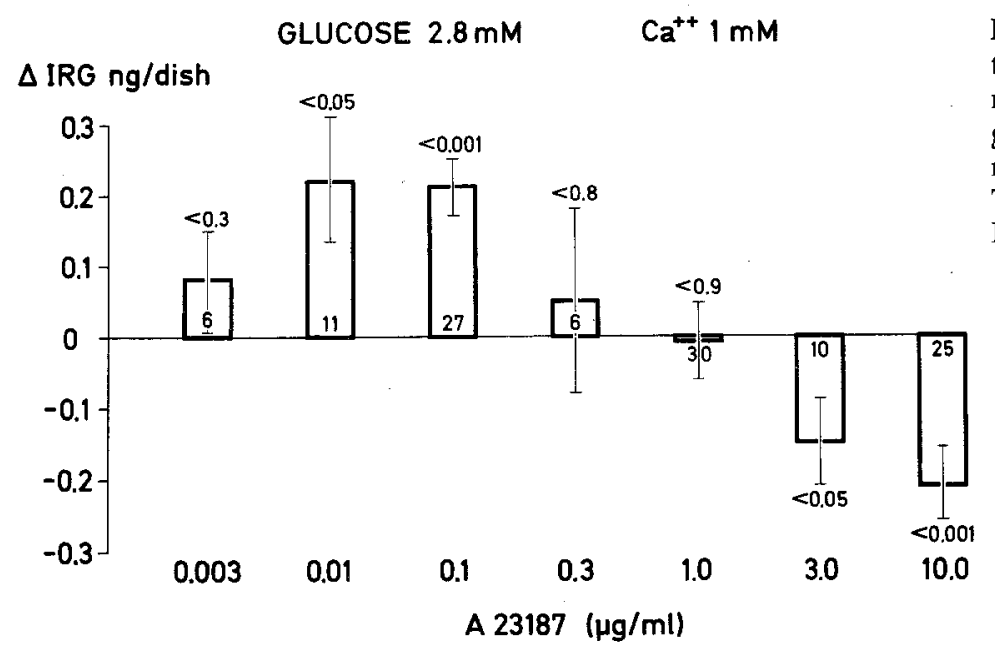

Fig. 1. Effect of different concentrations of A23187 on the glucagon release in the presence of $1 \mathrm{mM} \mathrm{Ca}^{2+}$. The results are expressed as the increment or decrement in glucagon release relative to control dishes i.e. $\triangle \mathrm{ng}$ IRG released/dish $/ 30 \mathrm{~min}$. Vertical lines represent $\pm \mathrm{SEM}$. The number of experiments is indicated in each bar. IRG, immunoreactive glucagon

Table 1. Effect of different concentrations of ionophore A23187 on glucagon release in the presence of $1 \mathrm{mM} \mathrm{Ca}^{2+}$. Release expressed as ng IRG/dish/30 min

\begin{tabular}{lllllr}
\hline $\begin{array}{l}\text { A 23187 } \\
(\mu \mathrm{g} / \mathrm{ml})\end{array}$ & Control & $\begin{array}{l}\text { Test } \\
(\mathrm{A} 23187)\end{array}$ & $\Delta$ & $p$ & $\mathrm{n}$ \\
\hline 0.003 & $0.61 \pm 0.05$ & $0.69 \pm 0.04$ & $0.08 \pm 0.07$ & $<0.3$ & 6 \\
0.01 & $0.59 \pm 0.07$ & $0.81 \pm 0.05$ & $0.22 \pm 0.09$ & $<0.05$ & 11 \\
0.1 & $0.50 \pm 0.04$ & $0.71 \pm 0.04$ & $0.21 \pm 0.04$ & $<0.001$ & 27 \\
0.3 & $0.46 \pm 0.10$ & $0.51 \pm 0.13$ & $0.05 \pm 0.13$ & $<0.8$ & 6 \\
1.0 & $0.58 \pm 0.05$ & $0.47 \pm 0.05$ & $-0.01 \pm 0.06$ & $<0.9$ & 30 \\
3.0 & $0.52 \pm 0.05$ & $0.37 \pm 0.06$ & $-0.15 \pm 0.06$ & $<0.05$ & 10 \\
10.0 & $0.51 \pm 0.04$ & $0.30 \pm 0.03$ & $-0.21 \pm 0.05$ & $<0.001$ & 25 \\
\hline
\end{tabular}

\section{Results}

\section{Dose-Response to the Ionophore}

Initial experiments were performed in the presence of $1.0 \mathrm{mM} \mathrm{Ca}^{2+}$ in the medium and different concentrations of the ionophore. As in all experiments reported here, except when high glucose concentrations are specifically mentioned, $2.8 \mathrm{mM}$ glucose was included in the incubation medium. The results are shown in Table 1. Under these conditions no significant alteration of glucagon release was achieved with an ionophore concentration of $0.003 \mu \mathrm{g} / \mathrm{ml}$. The minimal effective concentration of ionophore was $0.01 \mu \mathrm{g} / \mathrm{ml}$ and resulted in stimulation of glucagon release as did $0.1 \mu \mathrm{g} / \mathrm{ml}$. As the ionophore concentration was increased further the stimulatory effect on glucagon release was lost and at concentrations of 3 and 10 $\mu \mathrm{g} / \mathrm{ml}$ the release of glucagon was significantly depressed relative to paired control cultures. These results are best seen in Fig. 1 in which the changes in glucagon release in response to the different concentrations of ionophore are shown.

\section{Dose-Response to $\mathrm{Ca}^{2+}$}

The effect of ionophore A23187 at a concentration of $0.1 \mu \mathrm{g} / \mathrm{ml}$ was next tested in the presence of different concentrations of medium $\mathrm{Ca}^{2+}$. These results are shown in Fig. 2. In the absence of $\mathrm{Ca}^{2+}$ in the medium the ionophore had no effect on glucagon release. With $0.3 \mathrm{mM} \mathrm{Ca}^{2+}$ in the medium, a significant stimulation of glucagon release occurred. A larger stimulation of release was achieved with $1.0 \mathrm{mM} \mathrm{Ca}^{2+}$ whereas, at $2.5 \mathrm{mM} \mathrm{Ca}^{2+}$, no effect on glucagon release was observed.

Further studies were then performed in the presence of a high concentration of ionophore, $10 \mu \mathrm{g} / \mathrm{ml}$ (see Fig. 3). The response to different $\mathrm{Ca}^{2+}$ concentrations was again tested. With the high ionophore concentration a significant stimulation of glucagon release was present at a medium $\mathrm{Ca}^{2+}$ of only 0.03 $\mathrm{mM}$. Similarly, release was stimulated in the presence of 0.1 and $0.3 \mathrm{mM} \mathrm{Ca}^{2+}$. When the concentration of $\mathrm{Ca}^{2+}$ was raised to $1.0 \mathrm{mM}$ the release of glucagon was significantly depressed, in agreement with the results shown in the right hand bar of Fig. 1. 


\section{$\square$ GLUCOSE $2.8 \mathrm{mM}$ GLUCOSE $2.8 \mathrm{mM}+$ $\mathrm{ng} / \mathrm{dish}$ \\ A $23187(0.1 \mu \mathrm{g} / \mathrm{ml})$}

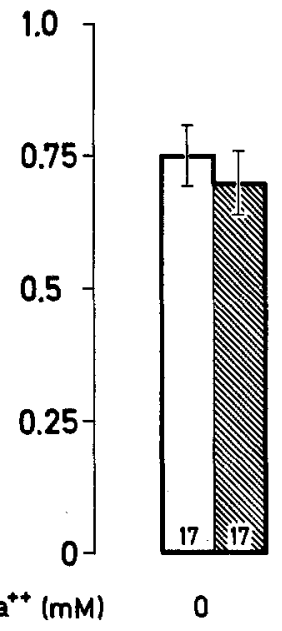

$\triangle I R G$ (ng/dish) 0.05

SEM (ng) 0.05

$<0.4$
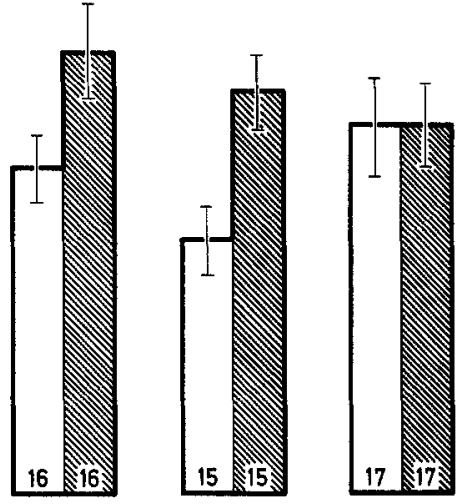

0.3
0.22
0.09
$<0.05$

1.0
0.29
0.08
$<0.005$

Fig. 2. Effect of different concentrations of $\mathrm{Ca}^{2+}$ on glucagon release in the presence and absence of $0.1 \mu \mathrm{g} / \mathrm{ml}$ A23187. Results expressed as ng IRG released/dish/30 min. Vertical lines represent \pm SEM. The number of experiments is indicated in each bar. IRG, immunoreactive glucagon
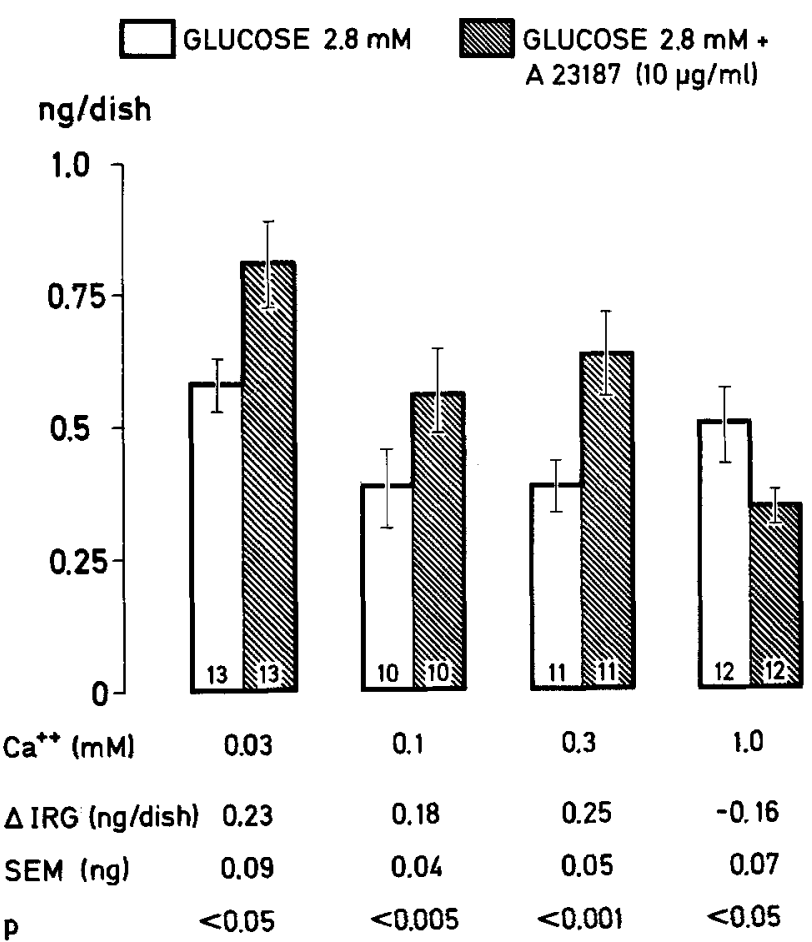

Fig. 3. Effect of different concentrations of $\mathrm{Ca}^{2+}$ on glucagon release in the presence and absence of $10 \mu \mathrm{g} / \mathrm{ml} \mathrm{A23187.} \mathrm{Results} \mathrm{are}$ expressed as ng IRG released/dish/30 min. Vertical lines represent \pm SEM. The number of experiments is indicated in each bar. IRG, immunoreactive glucagon

Table 2. Effect of different concentrations of $\mathrm{Ca}^{2+}$ on fractional glucagon release in the presence of either 0.1 or $10 \mu \mathrm{g} / \mathrm{ml} \mathrm{A23187.} \mathrm{The} \mathrm{IRG} \mathrm{release} \mathrm{is} \mathrm{expressed} \mathrm{as} \mathrm{the} \mathrm{\%} \mathrm{of} \mathrm{initial} \mathrm{IRG} \mathrm{content}$

\begin{tabular}{lccrll}
\hline $\begin{array}{l}\mathrm{Ca}^{2+} \\
(\mathrm{mM})\end{array}$ & Control & $\begin{array}{l}\mathrm{A} 23187 \\
0.1 \mu \mathrm{g} / \mathrm{ml}\end{array}$ & $\Delta$ & $p$ & $\mathrm{n}$ \\
\hline 0 & $9.3 \pm 0.9$ & $7.8 \pm 1.1$ & $-1.5 \pm 0.9$ & $<0.2$ & 17 \\
0.3 & $7.9 \pm 1.4$ & $9.7 \pm 1.0$ & $1.8 \pm 1.1$ & $<0.2$ & 16 \\
1.0 & $5.5 \pm 1.2$ & $9.4 \pm 2.0$ & $3.8 \pm 1.8$ & $=0.05$ & 15 \\
2.5 & $9.8 \pm 1.7$ & $9.6 \pm 1.7$ & $-0.2 \pm 1.5$ & $<0.95$ & 17 \\
& & $\mathrm{~A} 23187$ & & & \\
0.03 & & $10 \mu \mathrm{g} / \mathrm{ml}$ & & & 11 \\
0.1 & $5.9 \pm 2.2$ & $11.5 \pm 2.0$ & $2.5 \pm 2.0$ & $<0.3$ & 12 \\
0.3 & $5.9 \pm 1.3$ & $10.0 \pm 2.0$ & $4.1 \pm 1.9$ & $<0.1$ & 11 \\
1.0 & $4.0 \pm 0.7$ & $7.9 \pm 2.0$ & $3.9 \pm 1.6$ & $<0.05$ & 12 \\
\hline
\end{tabular}

\section{Glucagon Release Expressed as the Fraction of the Cellular Glucagon Content}

At the end of all the experiments shown in Fig. 2 and 3 , the content of glucagon remaining in the cultures was measured by acid ethanol extraction, dilution and immunoassay. Thus the amount of glucagon released could be expressed in terms of the original content of the cultures (i. e. glucagon release relative to glucagon content remaining at the end of the experiments plus the glucagon released). The results are shown in Table 2. The largest release of glucagon was $11.5 \%$ of the initial hormone content.

\section{Cation Specificity}

In order to assess the specificity of the response to $\mathrm{Ca}^{2+}$ and to see whether other cations could replace $\mathrm{Ca}^{2+}$ in modulating glucagon release, experiments were performed in the presence of different concentrations of $\mathrm{Mg}^{2+}, \mathrm{Ba}^{2+}$ and $\mathrm{Sr}^{2+}$. The results from 
Table 3. Effects of $\mathrm{Mg}^{2+}, \mathrm{Ba}^{2+}$ and $\mathrm{Sr}^{2+}$ on glucagon release in the presence and absence of A23187, expressed as $\mathrm{ng}$ IRG/dish/30 min

\begin{tabular}{|c|c|c|c|c|c|c|c|}
\hline a) $\mathrm{Ca}^{2+}$ & $\mathrm{Mg}^{2+}$ & & Control & $\begin{array}{l}\text { Test A23187 } \\
0.1 \mu \mathrm{g} / \mathrm{ml}\end{array}$ & $\triangle$ & $p$ & $\mathbf{n}$ \\
\hline & $\mathrm{mM}$ & & & & & & \\
\hline 1.0 & & 1.2 & $0.27 \pm 0.02$ & $0.61 \pm 0.07$ & $0.34 \pm 0.03$ & $<0.005$ & 10 \\
\hline 0 & & 1.2 & $0.31 \pm 0.02$ & $0.26 \pm 0.03$ & $-0.05 \pm 0.04$ & $<0.3$ & 10 \\
\hline 0 & & 12 & $0.25 \pm 0.02$ & $0.21 \pm 0.02$ & $-0.04 \pm 0.04$ & $<0.4$ & 10 \\
\hline 0 & & 24 & $0.21 \pm 0.02$ & $0.28 \pm 0.02$ & $0.07 \pm 0.03$ & $<0.1$ & 10 \\
\hline \multirow{7}{*}{ b) } & & & & Test A 23187 & & & \\
\hline & & $\mathrm{Ba}^{2+}$ & Control & $0.1 \mu \mathrm{g} / \mathrm{ml}$ & $\triangle$ & $p$ & $\mathbf{n}$ \\
\hline & & 0 & $0.46 \pm 0.05$ & $0.70 \pm 0.01$ & $0.23 \pm 0.08$ & $<0.05$ & 7 \\
\hline & & 0 & $0.58 \pm 0.06$ & $0.77 \pm 0.04$ & $0.19 \pm 0.08$ & $<0.1$ & 5 \\
\hline & & 0.03 & $0.65 \pm 0.10$ & $0.84 \pm 0.18$ & $0.20 \pm 0.23$ & $<0.5$ & 5 \\
\hline & & 0.1 & $0.70 \pm 0.27$ & $0.95 \pm 0.16$ & $0.25 \pm 0.15$ & $<0.2$ & 6 \\
\hline & & 0.3 & $1.24 \pm 0.09$ & $1.11 \pm 0.08$ & $-0.13 \pm 0.10$ & $<0.3$ & 7 \\
\hline c) & & & & Test A23187 & & & \\
\hline $\mathrm{Ca}^{2+}$ & & $\mathrm{Ba}^{2+}$ & Control & $10 \mu \mathrm{g} / \mathrm{ml}$ & $\triangle$ & $p$ & $\mathrm{n}$ \\
\hline & $\mathrm{mM}$ & & & & & & \\
\hline 0 & & 0 & $0.26 \pm 0.07$ & $0.34 \pm 0.04$ & $0.08 \pm 0.08$ & $<0.5$ & 5 \\
\hline 0 & & 0.1 & $0.33 \pm 0.02$ & $0.70 \pm 0.10$ & $0.37 \pm 0.10$ & $<0.025$ & 5 \\
\hline d) & & & & Test A23187 & & & \\
\hline $\mathrm{Ca}^{2+}$ & & $\mathrm{Sr}^{2+}$ & Control & $0.1 \mu \mathrm{g} / \mathrm{ml}$ & $\Delta$ & $p$ & $\mathrm{n}$ \\
\hline 1 & & 0 & $0.28 \pm 0.04$ & $0.35 \pm 0.05$ & $0.07 \pm 0.01$ & $<0.001$ & 11 \\
\hline 0 & & 0 & $0.44 \pm 0.07$ & $0.42 \pm 0.06$ & $-0.02 \pm 0.04$ & $<0.6$ & 11 \\
\hline 0 & & 1 & $0.44 \pm 0.06$ & $0.46 \pm 0.06$ & $0.02 \pm 0.04$ & $<0.6$ & 12 \\
\hline 0 & & 3 & $0.48 \pm 0.06$ & $0.36 \pm 0.05$ & $-0.12 \pm 0.05$ & $<0.05$ & 12 \\
\hline
\end{tabular}

experiments which were performed using $0.1 \mu \mathrm{g} / \mathrm{ml}$ ionophore are presented in Table 3 , where, in part (a), it can be seen that $1.0 \mathrm{mM} \mathrm{Ca}^{2+}$ in the presence of the standard $1.2 \mathrm{mM} \mathrm{Mg}^{2+}$ produced the expected ionophore induced stimulation of glucagon release. Removal of $\mathrm{Ca}^{2+}$, however, prevented the stimulatory effect of ionophore on release. As the $\mathrm{Mg}^{2+}$ concentration was increased to 12 or $24 \mathrm{mM}$, in the absence of both ionophore and $\mathrm{Ca}^{2+}$, the release of glucagon was diminished $(p<0.005)$. In the presence of ionophore increasing $\mathrm{Mg}^{2+}$ failed to stimulate glucagon release.

In the studies with $\mathrm{Ba}^{2+}$, results presented in Table 3 (b), $\mathrm{Ca}^{2+}$ produced its expected stimulation of glucagon release in the presence of the ionophore. In the presence of all three concentrations of $\mathrm{Ba}^{2+}$ tested $(0.03,0.1$ and $0.3 \mathrm{mM})$ and in the absence of $\mathrm{Ca}^{2+}$ the ionophore failed to induce glucagon release. It should be pointed out, however, that $0.3 \mathrm{mM} \mathrm{Ba}^{2+}$ alone stimulated glucagon release relative to the zero $\mathrm{Ca}^{2+}$ control $(p<0.005)$. For this reason $\mathrm{Ba}^{2+}$ was not tested at higher concentrations, but was tested using a higher ionophore concentration. Thus, using $10 \mu \mathrm{g} / \mathrm{ml}$ ionophore and $0.1 \mathrm{mM} \mathrm{Ba}^{2+}$ in the absence of $\mathrm{Ca}^{2+}$, a significant stimulation of glucagon release occurred
(Table 3 (c)). In the absence of $\mathrm{Ca}^{2+}$ and $\mathrm{Ba}^{2+}$ this high concentration of ionophore failed to stimulate release. Finally, the results of experiments with $\mathrm{Sr}^{2+}$ are shown in Table 3 (d). $\mathrm{Sr}^{2+}$ failed to mimick the effects of $\mathrm{Ca}^{2+} .1 \mathrm{mM} \mathrm{Sr}^{2+}$ had no effect upon glucagon release in the presence of ionophore while 3.0 $\mathrm{mM} \mathrm{Sr}{ }^{2+}$ caused a significant decrease of glucagon release in the presence of the ionophore.

\section{Effect of Different $\mathrm{Ca}^{2+}$ Concentrations in the Absence of Ionophore}

It was also possible to assess the effect of $\mathrm{Ca}^{2+}$ depletion on glucagon release under control conditions. Summing up the results of the experiments in Table 3 $\left(a, b\right.$ and d), glucagon release at $1 \mathrm{mM} \mathrm{Ca}^{2+}$ was 0.32 $\pm 0.03 \mathrm{ng} / \mathrm{dish} / 30 \mathrm{~min}$. Under $\mathrm{Ca}^{2+}$ free conditions it was $0.41 \pm 0.04 \mathrm{ng} / \mathrm{dish} / 30 \mathrm{~min}$. The difference, 0.08 \pm 0.03 was significant $(p<0.01, \mathrm{n}=25)$. A similar stimulation by $\mathrm{Ca}^{2+}$ depletion was also detected in the experiments shown in Fig. 2.

In view of this effect of $\mathrm{Ca}^{2+}$ depletion, we examined the effect of high $\mathrm{Ca}^{2+}$ concentrations on glucagon release. Under control conditions, that is in the absence of ionophore, glucagon release was mea- 


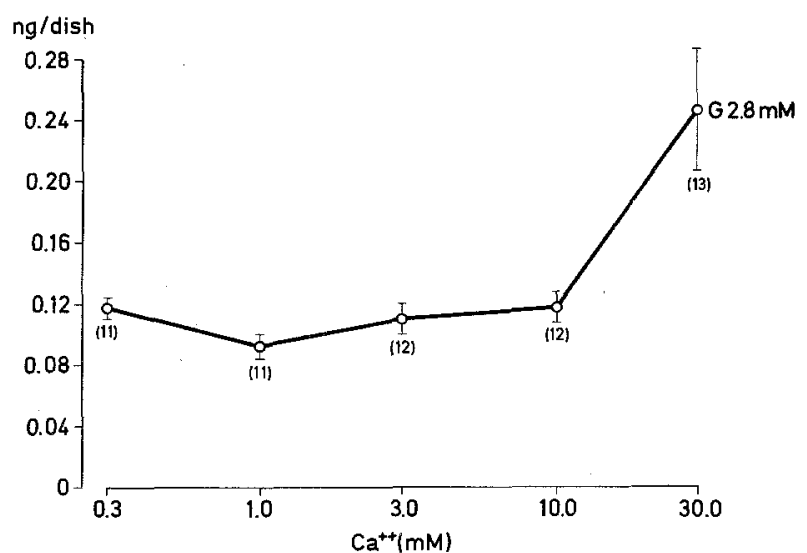

Fig. 4. Effect of different concentrations of $\mathrm{Ca}^{2+}$, in the absence of ionophore, on glucagon release. Results expressed as ng IRG released $/$ dish $/ 60 \mathrm{~min}$. Vertical lines represent $\pm S E M$. The number of experiments is indicated in parenthesis. IRG, immunoreactive glucagon

Table 4. Reversible effect of high $\mathrm{Ca}^{2+}$ concentration on glucagon release. Release was measured over two 60 min periods, the first in presence of either $\mathrm{Ca}^{2+} 3$ or $30 \mathrm{mM}$, the second in presence of $\mathrm{Ca}^{2+}$ $3 \mathrm{mM}$. Between the two incubations the dishes were washed three times before fresh medium was added. Release expressed as ng $\mathrm{IRG} / \mathrm{dish} / 60 \mathrm{~min} . \mathrm{n}=6$

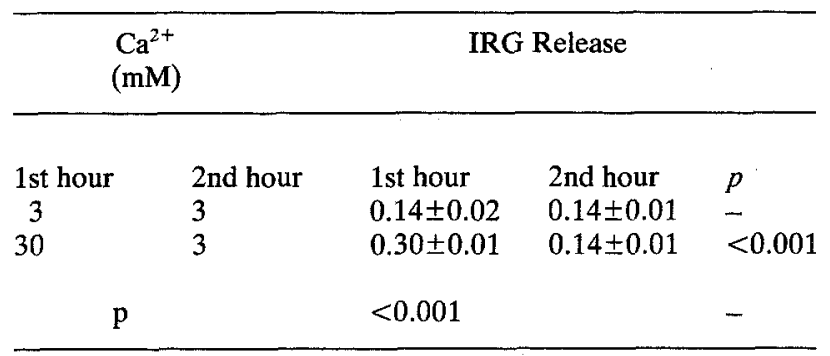

sured in the presence of $0.3,1.0,3.010 .0$ and 30.0 $\mathrm{mM} \mathrm{Ca}{ }^{2+}$. From the results shown in Fig. 4 it can be seen that a large stimulation of glucagon release occurred in the presence of $30 \mathrm{mM} \mathrm{Ca}^{2+}(p<0.01)$. Furthermore, as is shown in Table 4, the stimulatory effect of $30 \mathrm{mM} \mathrm{Ca}^{2+}$ is completely reversible.

\section{Effect of Ionophore on Glucose-Suppressed Glucagon Release}

Experiments were performed to see if the ionophore in the presence of $\mathrm{Ca}^{2+}$ in the medium could stimulate glucagon release in the face of a suppressive concentration of glucose. A comparison was made under control conditions $\left(1.0 \mathrm{mM} \mathrm{Ca}{ }^{2+}\right)$ of the glucagon released in the presence of $2.8 \mathrm{mM}$ and $16.7 \mathrm{mM}$ glucose. Release in $2.8 \mathrm{mM}$ glucose was $0.31 \pm 0.04$ $\mathrm{ng} / \mathrm{dish} / 30 \mathrm{~min}$ and in $16.7 \mathrm{mM}$ glucose it was $0.21 \pm$ $0.04, \triangle=-0.10 \pm 0.02, p<0.01, \mathrm{n}=5$. Thus high glucose suppressed glucagon release. In $16.7 \mathrm{mM}$ glucose $0.1 \mu \mathrm{g} / \mathrm{ml}$ ionophore almost doubled the glucagon release. Under these conditions, the release was $0.39 \pm 0.04 \mathrm{ng} / \mathrm{dish} / 30 \mathrm{~min}, \Delta=0.18 \pm 0.06, p<$ $0.05, \mathrm{n}=5$, demonstrating that stimulation of glucagon release is possible even during glucose suppression.

\section{Discussion}

It is clear from these data and those of Ashby and Speake [18] that $\mathrm{Ca}^{2+}$, in the presence of ionophore A23187, is able to stimulate glucagon release. This occurs when glucagon release is studied in the presence of low glucose, or inhibited in the presence of high glucose in the medium. Thus, as in previous studies in other release processes, the ionophore, by acting as a membrane carrier and permitting $\mathrm{Ca}^{2+}$ entry into cells, can mimic the effects of physiological stimulation. This has been shown for histamine release, fluid secretion, potassium efflux, amylase secretion, dopamine release, secretion by platelets and vasopressin and insulin release [6-18]. That the effect is not due to destruction of cells and liberation of cell contents seems apparent from experiments in which high ionophore concentrations were used. Under these conditions with normal $\mathrm{Ca}^{2+}(1 \mathrm{mM})$ the release of glucagon was inhibited. The ionophore is inactive in the absence of $\mathrm{Ca}^{2+}$ and stimulation is the result of a complex combination of ionophore and $\mathrm{Ca}^{2+}$ concentrations. With $1.0 \mathrm{mM} \mathrm{Ca}^{2+}$ in the medium, low concentrations of ionophore 0.01 and $0.1 \mu \mathrm{g} / \mathrm{ml}$ will stimulate release (Table 1); as the ionophore concentration is increased the stimulatory effect is lost and with further increase of ionophore to 3 and $10 \mu \mathrm{g} / \mathrm{ml}$, glucagon release is depressed. As the ionophore concentration is increased, so $\mathrm{Ca}^{2+}$ entry is able to reach excessively high levels and inhibition of release occurs, perhaps by inhibition of key enzyme systems involved in the release process, or in cell metabolism. In this respect these results are similar to those obtained on insulin release [15], when the ionophore in the presence of high medium $\mathrm{Ca}^{2+}$ gave less stimulation of release than in the presence of lower $\mathrm{Ca}^{2+}$ concentrations. Inhibition of glucose-induced insulin release by high concentrations of $\mathrm{Ca}^{2+}$ and $\mathrm{A} 23187$ has also been reported by Hellman [23]. This concept, that an increase in the cell cytosol $\mathrm{Ca}^{2+}$ concentration causes glucagon release and that excess $\mathrm{Ca}^{2+}$ is inhibitory, is further borne out by consideration of the results obtained at different $\mathrm{Ca}^{2+}$ concentrations. With a low ionophore concentration $(0.1 \mu \mathrm{g} / \mathrm{ml})$, stimulation of release occurs at 0.3 and $1.0 \mathrm{mM} \mathrm{Ca}^{2+}$ but is lost at $2.5 \mathrm{mM}$. With $10 \mu \mathrm{g} / \mathrm{ml} \mathrm{A23187,} \mathrm{low}$ 
$\mathrm{Ca}^{2+}$ concentrations of $0.03 \mathrm{mM}$ are effective, whereas $1.0 \mathrm{mM}$ is now inhibitory. This points to the requirement for careful control of intracellular $\mathrm{Ca}^{2+}$ in the intact cells. Under our experimental conditions, we presume that $0.1 \mu \mathrm{g} / \mathrm{ml}$ ionophore is rate limiting, whereas $10 \mu \mathrm{g} / \mathrm{ml}$ is not. Thus, at the latter concentration $0.03 \mathrm{mM} \mathrm{Ca}^{2+}$ is stimulatory. Assuming that 0.03 $\mathrm{mM}$ is the maximal concentration that can be achieved in the cell cytosol under these conditions, the resting concentration of free $\mathrm{Ca}^{2+}$ in the cell cytosol must obviously be less than this.

Replacement of $\mathrm{Ca}^{2+}$ by $\mathrm{Mg}^{2+}$ or $\mathrm{Sr}^{2+}$ failed to stimulate glucagon release in the presence of the ionophore at concentrations of $24 \mathrm{mM}$ for $\mathrm{Mg}^{2+}$ and 3 $\mathrm{mM}$ for $\mathrm{Sr}^{2+}$. Thus with respect to $\mathrm{Mg}^{2+}$ and $\mathrm{Sr}^{2+}$ the effect of $\mathrm{Ca}^{2+}$ is clearly specific. No effect of $\mathrm{Mg}^{2+}$ was detected and the effect of $\mathrm{Sr}^{2+}$ was inhibitory rather than stimulatory to glucagon release.

The situation regarding $\mathrm{Ba}^{2+}$ is more complicated. At $0.3 \mathrm{mM} \mathrm{Ba}^{2+}$ stimulated glucagon release even in the absence of ionophore, and $\mathrm{Ba}^{2+}$ has been shown to directly stimulate release processes in other cells. For instance insulin release $[15,24]$ and growth hormone release $[25,26]$ are both stimulated by the presence of $\mathrm{Ba}^{2+}$ in the medium. With the ionophore at $0.1 \mu \mathrm{g} / \mathrm{ml}$ no effect of $\mathrm{Ba}^{2+}$ on release was demonstrated and it was suspected that this might be due to the low transport ability of A23187 for this cation. It is known that the transport ability of $\mathrm{A} 23187$ for different cations is in the order $\mathrm{Mn}^{2+}>\mathrm{Ca}^{2+}>\mathrm{Mg}^{2+}>\mathrm{Sr}^{2+}>\mathrm{Ba}^{2+}$ [27]. Thus with $\mathrm{Ba}^{2+}$ at $0.1 \mathrm{mM}$, a concentration that does not stimulate alone, the ionophore at $10 \mu \mathrm{g} / \mathrm{ml}$ elicited a stimulation of glucagon release. The mechanism of $\mathrm{Ba}^{2+}$ induced release is unknown but it could be by mimickry of $\mathrm{Ca}^{2+}$ at its stimulatory site.

The demonstration of calcium induced glucagon release does not conflict with the reported calcium dependency of arginine stimulated glucagon release from the perfused rat pancreas [28]. It might, however, seem to be at variance with reports that $\mathrm{Ca}^{2+}$ depletion causes glucagon release in the perfused rat pancreas [29] and the confirmation of this effect reported here. Previous studies on the role of divalent cations in glucagon release in pieces of pancreas from duct-ligated rats have shown that omission of either $\mathrm{Ca}^{2+}$ or $\mathrm{Mg}^{2+}$ or both ions from the medium caused stimulation of glucagon release, whereas elevation of $\mathrm{Ca}^{2+}$ to $4 \mathrm{mM}$ had no effect and elevation of $\mathrm{Mg}^{2+}$ to $10 \mathrm{mM}$ was inhibitory [30]. Similarly, injection of $\mathrm{CaCl}_{2}$ into the pancreatic artery of dogs produced no effect upon glucagon release [31]. In our results a complex pattern of glucagon release in response to different $\mathrm{Ca}^{2+}$ concentrations was seen. Thus, in the absence of $\mathrm{Ca}^{2+}$ in the medium, release was greater than in the presence of $1.0 \mathrm{mM} \mathrm{Ca}^{2+}$. However, when high $\mathrm{Ca}^{2+}$ concentrations were studied, it was found that $30 \mathrm{mM} \mathrm{Ca}^{2+}$ caused a large release of glucagon. Thus the effects of different concentrations of $\mathrm{Ca}^{2+}$ are biphasic, both depletion and loading of the cells by $\mathrm{Ca}^{2+}$ being stimulatory. If we assume that the ionophore induced secretion process indicates a role for $\mathrm{Ca}^{2+}$ in the stimulus-secretion coupling mechanism, as it does in several cell types, it might be concluded that $30 \mathrm{mM} \mathrm{Ca}^{2+}$ (in the absence of ionophore) so loads the cell $\mathrm{Ca}^{2+}$ stores that saturation occurs and cell cytosol concentrations rise to stimulatory levels. We are currently unable to suggest a mechanism for the increased glucagon secretion observed under the conditions of $\mathrm{Ca}^{2+}$ depleted media.

Resolution of the role of $\mathrm{Ca}^{2+}$ in the physiological stimulation of glucagon release awaits precise measurements of cytosol $\mathrm{Ca}^{2+}$ in the A-cell. This is hampered by the lack of a pure A-cell preparation and even when this is achieved by the current techniques for the measurement of low concentrations of $\mathrm{Ca}^{2+}$ ions in cells.

Acknowledgements. The authors are grateful to Mrs. Theres Cuche, Mrs. Pascale Demay, Mrs. Marie-Paule Barrillat and Miss Marie-France Blanc, for their skilled technical assistance. These studies were supported by the Fonds National Suisse de la Recherche Scientifique (grants 3.1060.73, 3.8081.72, 3.553.75, 3.0310.73 and 3.0280.73).

\section{References}

1. Chaney, M. O., Demarco, P. V., Jones, N. D., Occolowitz, J. L.: The structure of A23187, a divalent cation ionophore. J. Amer. chem. Soc. 96, 1932-1933 (1974)

2. Reed, P. W., Lardy, H. A.: A23187: A divalent cation ionophore. J. biol. Chem. 247, 6970-6977 (1972)

3. Caswell, A. H., Pressman, B. C.: Kinetics of transport of divalent cations across sarcoplasmic reticulum vesicles induced by ionophores. Biochem. biophys. Res. Commun. 49, 292-298 (1972)

4. Pressman, B. C.: Properties of ionophores with broad range cation selectivity. Fed. Proc. 32, 1698-1703 (1973)

5. Wong, D. T., Wilkinson, J. R., Hamill, R. L., Horng, J.-S.: Effects of antiobiotic ionophore, A23187, on oxidative phosphorylation and calcium transport of liver mitochondria. Arch. Biochem. Biophys. 156, 578-585 (1973)

6. Foreman, J. C., Mongar, J. L., Gomperts, B. D.: Calcium ionophores and movement of calcium ions following the physiological stimulus to a secretory process. Nature $\mathbf{2 4 5}$, 249-251 (1973)

7. Cochrane, D. E., Douglas, W. W.: Calcium induced extrusion of secretory granules (exocytosis) in mast cells exposed to $48 / 80$ or the ionophores A23187 and X537A. Proc. nat. Acad. Sci. (Wash.) 71, 408-412 (1974)

8. Prince, W. T., Rasmussen, H., Berridge, M. J.: The role of calcium in fly salivary gland secretion analysed with the ionophore A23187. Biochim. biophys. Acta (Amst.) 329, 98-107 (1973) 
9. Selinger, Z., Eimerl, S., Schramm, M.: A calcium ionophore simulating the action of epinephrine on the $\alpha$-adrenergic receptor. Proc. nat. Acad. Sci. (Wash.) 71, 128-131 (1974)

10. Eimerl, S., Savion, N., Heichal, O., Selinger, Z.: Induction of enzyme secretion in rat pancreatic slices using the ionophore A23187. J. biol. Chem. 249, 391-393 (1974)

11. Williams, J. A., Lee, M.: Pancreatic acinar cells: Use of $\mathrm{Ca}^{++}$ ionophore to separate enzyme release from the earlier steps in stimulus-secretion coupling. Biochem. biophys. Res. Commun. 60, 542-548 (1974)

12. Holz, R. W.: The release of dopamine from rat striatum by the ionophores X537A and A23187. Biochim. biophys. Acta (Amst.) 375, 138-152 (1975)

13. Feinman, R. D., Detwiler, T. C.: Platelet secretion induced by divalent action ionophores. Nature 249, 172-173 (1974)

14. Russell, J. T., Hansen, E. L., Thorn, N. A.: Calcium and stimulus-secretion coupling in the neurohypophysis. II. $\mathrm{Ca}^{++}$-ionophore A23187-induced release of vasopressin from isolated rat neurohypophysis. Acta endocr. (Kbh.) 77, 443-450 (1974)

15. Wollheim, C. B., Blondel, B., Trueheart, P. A., Renold, A. E., Sharp, G. W. G.: Calcium-induced insulin release in monolayer culture of the endocrine pancreas. Studies with ionophore A23187. J. biol. Chem. 250, 1354-1360 (1975)

16. Karl, R. C., Zawalich, W. S., Ferrendelli, J. A., Matschinsky, F. M.: The role of $\mathrm{Ca}^{2+}$ and adenosine $3^{\prime}-5^{\prime}$-monophosphate in insulin release induced in vitro by the divalent cation ionophore A23187. J. biol. Chem. 250, 4575-4579 (1975)

17. Charles, M. A., Lawecki, J., Pictet, R., Grodsky, G. M.: Insulin secretion. Interrelationships of glucose, adenosine $3^{\prime}-5$ '-monophosphate, and calcium.J. biol. Chem. 250, 6134-6140 (1975)

18. Ashby, J. P., Speake, R. N.: Insulin and glucagon secretion from isolated islets of Langerhans. The effect of calcium ionophores. Biochem. J. 150, 89-96 (1975)

19. Marliss, E. B., Wollheim, C. B., Blondel, B., Orci, L., Lambert, A. E., Stauffacher, W., Like, A. A., Renold, A. E.: Insulin and glucagon release from monolayer cell cultures of pancreas from newborn rats. Europ. J. clin. Invest. 3, 16-26 (1973)

20. Lambert, A. E., Blondel, B., Kanazawa, Y., Orci, L., Renold, A. E.: Monolayer cell-culture of neonatal rat pancreas: Light microscopy and evidence of immunoreactive insulin synthesis and release. Endocrinology 90, 239-248 (1972)

21. Orci, L., Like, A. A., Amherdt, M., Blondel, B., Kanazawa, Y., Marliss, E. B., Lambert, A. E., Wollheim, C. B., Renold, A. E.: Monolayer cell culture of neonatal rat pancreas: An ultrastruc- tural and biochemical study of functioning endocrine cells. J. Ultrastruct. Res. 43, 270-297 (1973)

22. Unger, R. H., Aguilar-Parada, E., Muller, W. A., Eisentraut, A. M.: Studies on pancreatic alpha cell function in normal and diabetic subjects. J. clin. Invest. 49, 837-848 (1970)

23. Hellman, B.: Modifying actions of calcium ionophores on insulin release. Biochim. biophys. Acta (Amst.) 399, 157-169 (1975)

24. Milner, D. G., Hales, C. N.: The interaction of various inhibitors and stimuli of insulin release studies with rabbit pancreas in vitro. Biochem. J. 113, 473-479 (1969)

25. Schofield, J. G., McPherson, M.: Increase in pituitary adenosine $3^{\prime} 5^{\prime}$-monophosphate content and potentiation of growth-hormone release from heifer anterior pituitary slices incubated in the presence of 3-isobutyl-1-methylxanthine. Biochem. J. 142, 295-300 (1974)

26. Schofield, J. G., Mira-Moser, F., Schorderet, M., Orci, L.: Somatostatin inhibition of rat growth hormone release in vitro in the presence of $\mathrm{BaCl}_{2}$ or 3-isobutyl-1-methylxanthine. FEBS Letters 46, 171-174 (1974)

27. Reed, P. W.: A23187: A divalent cation ionophore. Fed. Proc. 31, 432 (Abstr.) (1972)

28. Gerich, J. E., Frankel, B. J., Fanska, R., West, L., Forsham, P. H., Grodsky, G. M.: Calcium dependency of glucagon secretion from the in vitro perfused rat pancreas. Endocrinology 94, 1381-1386 (1974)

29. Leclercq-Meyer, V., Rebolledo, O., Marchand, J., Malaisse, W. J.: Glucagon release: Paradoxical stimulation by glucose during calcium deprivation. Science 189, 897-899 (1975)

30. Leclercq-Meyer, V., Marchand, J., Malaisse, W. J.: The effect of calcium and magnesium on glucagon secretion. Endocrinology 93, 1360-1370 (1973)

31. Kuzuya, T., Kajinama, H., Ide, T.: Effect of intrapancreatic injection of potassium and calcium on insulin and glucagon secretion in dogs. Diabetes 23, 55-60 (1974)

Received: February 6, 1976, and in revised form: April 14, 1976

Dr. C. B. Wollheim

Institut de Biochimie Clinique

Sentier de la Roseraie

$\mathrm{CH}-1211$ Genève 4

Switzerland 